\title{
Pelatihan Kepada Guru SD untuk Mengajarkan Konsep Luas Bidang Datar dengan Menggunakan MEQIP (Mathematic Eduation Quality Improvement)
}

\author{
Dydik Kurniawan ${ }^{1 *}$, Tri Wahyuningsih ${ }^{2}$, Fara Virgianita Pangadongan ${ }^{3}$
}

1,2,3 Program Studi Pendidikan Guru Sekolah Dasar, FKIP Universitas Mulawarman

\section{A R T I C L E I N F O}

Article history:

Received 20 February 2019

Received in revised form

10 March 2019

Accepted 30 April 2019

Available online 27 May 2019

\section{Kata Kunci:}

Luas Bidang Datar, MEQIP

Keywords:

Flat Field Area, MEQIP
A B S T R A K

Pengabdian ini bertujuan memberikan pelatihan kepada guru SD untuk Mengajarkan Konsep Luas Bidang Datar dengan menggunakan MEQIP (Mathematic eduation quality Improvement) di SD Samarinda Kota. Metode pelaksanaan kegiatan pengabdian pada masyarakat ini adalah "Pelatihan". Adapun kegiatan yang dilaksanakan adalah: Persiapan, Pelaksanaan, dan Evaluasi. Keberhasilan kegiatan pelatihan ini akan dievaluasi melalui proses yang dilihat dari aktivitas peserta mengkuti kegiatan pelatihan. Sasaran kegiatan pengabdian masyarakat adalah para guru SD Se-Kota Samarinda yang direncanakan dan di undang berjumlah 43 orang. Pelaksanan kegiatan ini dilaksanakan dalam bentuk penyampaian materi dan presentasi hasil pelatihan. Materi yang diberikan terdiri dari 5 materi, yaitu Sumber dan media pembelajaran serrta pentingnya alat peraga dalam pembelajaran matematika di SD, Pengenalan MEQIP. Peragaan penggunaan alat peraga luas segitiga, segiempat dan lingkaran. Dari hasil pelatihan guru-guru mampu memanfaatkan alat peraga yang tersedia di sekolah secara maksimal, dan mampu mengajarkan konsep-konsep matematika dengan benar sehingga siswa dapat mencapai tujuan pembelajaran dengan baik.

\section{A B S T R A C T}

This service aims to provide training to teachers elementary school to teach the concept of flat field area by using MEQIP (Mathematic eduation quality improvement) in Samarinda. This method for implementing community service activities is "Training". The activities carried out are: Preparation, Implementation and Evaluation. The success of this training activity will be evaluated through a process that is seen from activities of the participants that following the training activities. The target of community service activities is 43 elementary school teachers in Samarinda. Implementation of this activity is carried out in the form of material delivery and presentation of the results that training. The material provided consisted of 5 materials, they are source and learning media and also importance of teaching aids in mathematics learning in elementary school,the Introduction of MEQIP. Demonstration of broad props of triangles, squares and circles. From the results of training the teachers are able to make the most available teaching aids in the school, and able to teach mathematical concepts correctly so the students can achieve the learning goals.

\footnotetext{
* Corresponding author.

E-mail addresses: Dydikkurniawan345@gmail.com (Dydik kurniawan)
} 


\section{Pendahuluan}

Matematika merupakan ilmu logika yang mendasari berbagai disiplin dan kemajuan daya pikir manusia. (Usman, 1990:52) yang mengungkapkan bahwa di bidang teknologi, informasi dan komunikasi matematika berkembang pesat. Oleh karena itu untuk menguasai dan menciptakan teknologi di masa yang akan datang, diperlukan penguasaan matematika yang kuat sejak dini.

Matematika salah satu materi yang sangat diperlukan dalam perkembangan ilmu pengetahuan dan teknologi. Mata pelajaran matematika perlu diberikan kepada semua peserta didik dari tingkat sekolah dasar sampai tingkat lanjutan atas untuk membekali peserta didik dengan kemampuan berpikir logis, analitis, sistematis, kritis, dan kreatif, serta kemampuan bekerjasama, kompetensi memperoleh, mengelola, dan memanfaatkan informasi untuk bertahan hidup pada keadaan yang selalu berubah, tidak pasti, dan kompetitif (Indayani ,2015).

Matematika adalah ilmu universal yang mendasari perkembangan teknologi modern saat ini. Mengapa demikian?, karena matematika memiliki peran penting yang menjadi sarana dalam pemecahan masalah kehidupan (Misel, 2016) (Dewimarni, 2017). Pentingnya matematika dalam pembelajaran mulai dari jenjang sekolah dasar sampai perguruan tinnggi yang berfungsi dalam mengembangkan daya nalar kemampuan berpikir 16 (Afifah, 2012; Rasyid, 2017; Somawati, 2018). Konsep-konsep dalam matematika yang abstrak tersusun berjenjang dan berurutan masih diperlukan pembuktian-pembuktian khusus, sehingga dalam mempelajari matematika konsep sebelumnya harus dikuasai karena merupakan prasyarat untuk melanjutkan konsep berikutnya (Misel, 2016). Pembuktian merupakan hal yang sering dilakukan dalam bidang matematika. Pada umumnya masih banyak yang belum mengetahui cara yang digunakan untuk melakukan pembuktian dalam matematika. Berbicara tentang bukti matematika, terkadang kita temui berbagai kalangan, umumnya siswa dan mahasiswa yang cenderung berpikir bahwa bukti tidak begitu penting di dalam mempelajari matematika (Sabri, 2003). Pada tahap awal pembuktian matematika bukanlah sesuatu yang mudah. Kejadian inilah yang menjadikan seseorang malas untuk memahami bukti dalam matematika (Putri, 2011). Dikalangan pelajar dan mahasiswa bukti adalah alat yang hanya digunakan, oleh matematikawan, untuk menjelaskan pernyataan matematika yang telah diketahui kebenarannya (Sabri,2003:2). Dalam pembuktian matematika terdapat beberapa metode pembuktian sederhana dengan menggunakan aturanaturan logika dasar, misalnya bukti langsung, bukti tak langsung, bukti dengan kontradiksi, bukti ketunggalan, penyanggahan bukti dengan counter example, bukti dengan induksi matematika (Putri, 2011). Adapun bukti yang digunakan dapat berupa bukti formal dan bukti informal (Suandito ,2017).

Beralasan sifat matematika yang abstrak, tidak sedikit siswa yang masih menganggap matematika itu sulit. Hal ini sesuai dengan yang dikemukakan Russefendi bahwa "terdapat banyak anak-anak setelah belajar matematika bagian yang sederhana, banyak yang tidak dipahaminya, dan banyak konsep yang dipahami secara keliru. Matematika dianggap sebagai ilmu yang sukar dan banyak memperdayakan" (Surya, 2012: 2) (Novitasari ,2016).

Hadi (2005, pp.11-12) menyatakan bahwa proses pembelajaran mtematika selama ini yang terjadi belum sesuai dengan yang diharapkan, yaitu masih berpusat pada guru.Selama ini siswa hanya duduk diam sambil mendengarkan penjelasan dari gurunya kemudian mencatat kembali apa yang dicatat oleh guru di depan kelas atau papan tulis selanjutnya mengerjakan soal latihan yang soal dan penyelesaiannya tidak berbeda jauh dengan apa yang dicontohkan oleh guru di depan kelas (Alin ,2015).

Kenyataan di lapangan khususnya di sekolah wilayah kota smarinda masih banyak siswa yang kurang mampu mempelajari matematika di sekolah dasar. Hal ini telah ditandai dengan rendahnya hasil belajar siswa yang masih jauh dari batas KKM (Kriteria Ketuntasan Minimal) yang ditetap di sekolah, kurangnya minat siswa untuk belajar matematika, siswa memandang bahwa matematika sulit untuk dipelajari, membosankan dan lain sebagainya. Hal ini menjadi tantangan bagi guru pengajar matematika di sekolah dasar. Seorang guru pengajar matematika hendaknya bertanggung jawab terhadap hasil belajar peserta didiknya. Dari hasil wawancara dari beberapa guru yang ada di sekolah SDN 008 Samarinda Kota guru tersebut mengungkapkan hal ini dikarenakan masih kurangnya pemahaman dan kurang terampilnya guru terhadap pemanfaatan media pembelajaran khususnya Meqip dalam hal menanamkan Konsep pada matapelajaran matematika.

Tujuan pendidikan menurut undang-undang dapat diartikan lebih luas menjadi sebuah tatanan perilaku individu dalam peranya sebagai warga Negara. membentuk anak menjadi warga negara yang baik. Karena pendidikan merupakan bimbingan terhadap perkembangan manusia menuju ke arah citacita tertentu, maka masalah pokok bagi pendidikan ialah memiliki sebuah tindakan agar dapat mencapai sebuah tujuan. Undang-undang No. 20 Tahun 2003 seharusnya menjadi suatu landasan bagi proses pendidikan yang berlangsung di Indonesia semenjak diberlakukan. Namun demikian, hal ini berbeda dengan apa yang dipraktikkan oleh para pendidik di sekolah saat ini. Satu pertanyaan untuk menguji 
apakah pendidikan di Indonesia secara hakiki dilandaskan pada UU No. 20 tahun 2003 adalah "apakah proses pembelajaran yang dilakukan oleh guru saat ini ditujukan untuk menjadikan potensi peserta didik berkembang sebagaimana mestinya atau hanya sekedar ditujukan untuk menyampaikan materi yang dipersepsi oleh guru-guru yang hanya mengasah kemampuan otak?" Maka dari itu, untuk merubah dan mewujudkan perubahan sistem pendidikan dibutuhkan beberapa upaya yang harus dilakukan salah satunya melalui penulisan artikel ini diharapkan dapat mengubah paradigma khalayak tentang pendidikan dan peran pekerja sosial yang penting di dalamnya (Yusuf ,2015).

Zainal (2016) mengemukakan bahwa tujuan pendidikan bisa diklasifikasikan menjadi tiga kategori, yaitu keterampilan berpikir, tingkah laku (perilaku), dan keterampilan fisik yang mewakili tiga ranah (domain) pendidikan yaitu ranah kognitif (cognitive), afektif (affective), dan psikomotorik (psychomotor). Untuk itu penilaian hasil belajar seharusnya mencakup tiga ranah pendidikan tersebut. Khusus pada pembelajaran matematika disekolah dasar, guru dihadapkan pada kondisi pembelajaran yang kurang kondusif untuk dapat meningkatkan hasil belajar yang diharapkan kondisi tersebut disebabkan karena matematika yang obyek pemecahannya abstrak dipelajari siswa sekolah dasar yang tingkat berfikirnya konkrit. Permasalahan lainnya terdapat pada guru. Kebanyakan guru dalam mengajar di kelas masih kurang memperhatikan kemampuan berpikir siswa, media yang digunakan kurang bervariasi, dan sebagai akibatnya motivasi belajar siswa menjadi sulit ditumbuhkan dan pola belajar cenderung menghafal dan mekanistis. Ditambah lagi dengan penggunaan pendekatan pembelajaran yang cenderung membuat siswa pasif dalam proses belajar- mengajar, yang membuat siswa tidak tertarik untuk mengikuti pelajaran. Oleh karena itu, dibutuhkan ketekunan, keuletan, perhatian, dan motivasi yang tinggi dari guru untuk membantu siswa dalam memahami materi yang diajarkan pada pembelajaran matematika.

Untuk mengatasi permasalahan di atas, langkah yang perlu dilaksanakan adalah dengan menggunakan media MEQIP (Mathematic eduation quality Improvement). Media MEQIP (Mathematic eduation quality Improvement) tersebut dapat membelajarkan siswa secara optimal. Penggunaan media dapat dimanipulasikan sesuai dengan kebutuhan. Mawardi (2017: 29) mengatakan media adalah pembelajaran segala sesuatu yang dapat digunakan sebagai sarana informasi materi pembelajaran sedangkan, menurut Dina Indriana (2011:27) dasar terpenuhinya kebutuhan dan tercapainya tujuan pembelajaran. Menurut Atmaja (2016), pengertian peran dapat didefinisikan sebagai suatu rangkaian perasaan, ucapan dan tindakan, sebagai suatu pola hubungan unik yang ditunjukkan oleh individu terhadap individu lain. Sedangkan menurut Aziz (2008), bermain peran adalah berakting sesuai dengan peran yang telah ditentukan terlebih dahulu untuk tujuan-tujuan tertentu seperti menghidupkan kembali suasana historis misalnya mengungkapkan kembali perjuangan para pahlawan kemerdekaan atau mengungkapkan kemungkinan keadaan yang akan datang.

Menurut Sukayati dkk MEQIP (Matehematics Education Quality Improvement Program) adalah program peningkatan mutu pembelajaran matematika yang telah direview oleh pakar matematika dari beberapa perguruan tinggi di Indonesia dan telah diujicobakan di berbagai propinsi di Indonesia (Sumarni ,2013).

Media merupakan lingkungan belajar yang sangat menunjang untuk tercapainya optimalisasi dalam pembelajaran, karena media merupakan jembatan belajar yang awalnya terdapat benda-benda konkret seperti pengalaman anak. Pada jembatan selanjutnya terdapat semi konkret seperti benda-benda tiruan. Berikutnya lagi terdapat semi abstrak berupa gambar-gambar, dan selanjutnya terdapat abstrak berupa kata-kata. Melalui media bidang datar materi yang bersifat abstrak dapat menjadi konkret. Artinya, siswa akan mengetahui dan melihat komponen - komponen bidang datar. Menurut Ambuko Benson, Florence Odera (2013:16). Media is expected to play a critical role in enhancing academic performance. (Media diharapkan dapat memainkan peran penting dalam meningkatkan prestasi akademik). Suranto (2005:18) menyatakan bahwa media adalah suatu sarana yang digunakan untuk menyampaikan pesan dari seorang komunikator kepada komunikan. Trini Prastati (2005:3) memberi makna media sebagai apa saja yang dapat menyalurkan informasi dari sumber informasi ke penerima informasi (Purwono, 2014).

Dalam bahasa Arab kata media disebut dengan pengantar pesan dari pengirim kepada penerima 6 (1982) berpendapat bahwa media adalah Information carying technologies that can be used for instruction....... The media instruction, consequently are extensions of the teacher. Menurutnya media adalah teknologi pembawa pesan yang dapat dimanfaatkan untuk keperluan pembelajaran. Jadi media adalah perluasan dari guru.7 Pengertian yang dikemukakannya tidak jauh beda dengan pengertian yang dikemukakan oleh Asociation of Education Comunication Technology (AECT), yang mana media diartikan dengan segala bentuk dan saluran yang dapat dipergunakan untuk proses penyalur pesan.8 Dari kedua pendapat tersebut dapat dipahami bahwa media adalah berkaitan dengan perantara yang berfungsi menyalurkan pesan dan informasi dari sumber yang akan diterima oleh si penerima pesan yang terjadi dalam proses pembelajaran (Mahnun ,2012). 
Selain itu dengan media siswa dapat melihat secara langsung bentuk bentuk sisi dan sekaligus mengingat kembali tentang luas luas bangun datar. Melalui media pembelajaran yang efektif dan efisien, menyebabkan seimbangnya kemampuan kognitif, afektif dan psikomotorik. Untuk itu, guru sebagai tenaga pengajar dan pendidik harus selalu meningkatkan kualitas profesionalismenya yaitu dengan cara memberikan kesempatan belajar kepada siswa dengan melibatkan siswa secara efektif dalam proses pembelajaran dengan memanfaatkan media yang ada. Hal ini juga sesuai dengan apa yang diterapkan pada kurikulum 2013 yaitu: mengamati, menanyakan, mengumpulkan informasi, mengasosiasi, dan mengkomunikasikan. Rahmanelli (2005:237) menyatakan apabila anak terlibat dan mengalami sendiri serta ikut serta dalam proses pembelajaran maka hasil belajar siswa akan lebih baik, disamping itu pelajaran akan lebih lama diserap dalam ingatan siswa. Untuk itu, implementasi media pembelajaran harus dilakukan sebaik mungkin untuk menciptkan dan meningkatkan hasil belajar. Dengan media pembelajaran kepada siswa diharapkan siswa dapat meningkatkan aktifitas belajarnya. Berdasarkan uraian di atas, peneliti tertarik melakukan pengabdian dengan judul "Mengajarkan Konsep Luas Bidang Datar di SD menggunakan MEQIP (Mathematic eduation quality Improvement)."

\section{Metode}

Metode pelaksanaan kegiatan pengabdian pada masyarakat ini adalah "Pelatihan". Adapun kegiatan yang dilaksanakan adalah:

1. Persiapan

a. Memohon ijin pelaksanaan kepada Dinas Pendidikan Kota Samarinda.

b. Mengadakan koordinasi dengan FKIP UNMUL.

2. Pelaksanaan

Kegiatan pelatihan dilaksanakan pada September 2018. Kegiatan pengabdian yang akan dilaksanakan meliputi:

a. Pembukaan

b. Memberikan orientasi

1) Melakukan eksplorasi hambatan dalam pelaksanaan dalam proses pembelajran pada materi Bidang Datar.

2) Pemberian materi pelatihan keterampilan dalam mengajarkan konsep Bidang datar menggunakan Meqip (Mathematic eduation quality Improvement) kepada peserta didik.

3) Tanya jawab untuk meningkatkan pemahaman tentang Konsep bidang datar.

Pelatihan penerapan Konsep Bidang datar menggunakan Meqip (Mathematic eduation quality Improvement).

3. Evaluasi

Keberhasilan kegiatan pelatihan ini akan dievaluasi melalui proses yang dilihat dari aktivitas peserta mengkuti kegiatan pelatihan. Sasaran kegiatan pengabdian masyarakat adalah para guru SD Se Kota Samarinda yang direncanakan dan di undang berjumlah 43 orang. Pelatihan difasilitatori oleh Dosen Program Studi Pendidikan Matematika FKIP UNMUL. Adapun fasilitator kegiatan ini adalah: Dydik Kurniawan, S.Pd, M.Pd (Dosen FKIP UNMUL) dan Dra. Tri Wahyuningsih, M.Si (Dosen UNMUL)

\section{Hasil dan pembahasan}

Berdasarkan hasil Pelaksanaan kegiatan pelatihan MEQIP sesuai dengan jadwal yaitu Pada tanggal 17-18 Oktober 2018. Hasil evaluasi Pelatihan yang telah dilaksanakan selama dua hari bertempat di SDN 008 Samarinda Kota. Pada Materi 1 Ibu Dra Hj. Tri Wahyuningsih, M.Si menyampaikan materi tentang "Sumber dan Media Pembelajaran dan Pentingan Alat Peraga Bagi Penanaman Konsep di SD". Pada Materi ini diperoleh banyak respon dari guru, salah satunya adalah pengelolaan waktu atau management waktu kegiatan pembelajaran yang menggunakan alat peraga. Melalui diskusi ini guru-guru memahami bahwa waktu bukanlah kendala dalam melaksanakan pembelajaran yang kreatif dan menyenangkan dengan menggunakan alat peraga, hal yang terpenting dari pelakasanakan kegiatan pembelajaran adalah persiapan guru.

Pada materi kedua Dydik Kurniawan M.Pd menyampaikan tentang pengenalan alat MEQIP dan Konsep-konsep matematika apa saja yang dapat diajarkan. Dari hasil penyampain ini guru cukup terkagum, ternyata hampir semua konsep matematika di SD dapat ditemukan alat peraganya. Beberapa guru tertarik untuk mempelajari alat-alat lainnya dan tertarik dengan CD interaktif yang ada pada paket MEQIP tersebut. Guru-guru juga ikut merencakan untuk dapat mempelajari hal-hal lain selain luas bidang datar. Sehubungan dengan waktunya sudah habis, maka pembicara menutup kegiatan di hari pertama dan akan dilanjutkan kembali esok hari. 
Pada materi ketiga tentang bagaimana mempelajari penemuan rumus luas persegi panjang. Rumus luas persegi panjang inilah yang nantinya akan menjadi modal untuk mencari rumus luas bangun lainnya. Jadi dengan menggunakan pendekatan rumus luas persegi panjang para guru dituntun untuk menemukan rumus bangun datar lainnya. Kemudian guru-guru dibagi dalam beberapa kelompok yang terdiri dari 6-7 orang. Setiap kelompok mendapatkan 1 set alat perga yang terdiri dari bangun segitiga, jajargenjang, belahketupat, layang-layang, trapesium dan lingkaran. Setelah mendapatkan alat perag, guru-guru diminta untuk mencoba menyusun potongan-potongan segitiga hingga berbentuk persegi panjang. Setelah selesai menyusun potongan-potongan tersebut guru diminta menganalisis sehingga dapat ditemukan rumus luas segitiga seperti yang mereka ketahui. Pada materi ini dilanjutkan untuk memandu guru-guru dalam menemukan rumus-rumus bangun datar menggunakan pendekatan luas persegi panjang. Kali ini bangun yang akan diajarkan adalah bangun jajargenjang, belahketupat, layang-layang, trapesium dan lingkaran. Setelah mendapatkan alat perag, guru-guru diminta untuk mencoba menyusun potongan-potongan bangun-bangun tersebut hingga berbentuk persegi panjang.

Setelah selesai guru diminta menganalisis sehingga dapat ditemukan rumus luas bangun-bangun tersebut seperti yang mereka ketahui. Dari beberapa kelompok dapat dilahat guru-guru kesulitan untuk menempatkan potongan-potongan tersebut hingga membentuk bangun persegi panjang. Namun guruguru tetap semangat mencoba, hal ini dikarenakan hal tesebut menyenangkan dan mengasah keterampilan mereka. Guru-guru beranggapan jika mereka saja menyukai kegiatan ini apalagi siswa-siswa mereka.

Pada materi ini Dydik Kurniawan, M.Pd kembali melanjutkan untuk memandu guru-guru dalam menemukan rumus bangun datar, yaitu bangun datar lingkaran menggunakan pendekatan luas persegi panjang. Setelah mendapatkan alat perag, guru-guru diminta untuk mencoba menyusun potonganpotongan bangun-bangun tersebut hingga berbentuk persegi panjang. Setelah selesai menyusun potongan-potongan tersebut guru diminta menganalisis sehingga dapat ditemukan rumus luas bangunbangun tersebut seperti yang mereka ketahui. Dari beberapa kelompok dapat dilahat guru-guru kesulitan untuk menempatkan potongan-potongan tersebut hingga membentuk bangun persegi panjang. Karena bentuk lingkaran yang mereka rasa tidak mungkin akan membentuk persegi panjang, namun mereka tetap mencoba sampai mendapatkannya, walau dengan tuntunan mentor/ nara sumber. Pada kesempatan ini setiap kelompok diminta untuk mempresentasikan hasil diskusi mereka. Setiap kelompok mendapat kesempatan untuk mepresentasikan penemuan rumus satu buah bangun datar. Disetiap awal presentasi guru-guru membangkitkan semangat mereka dan para peserta pelatihan dengan menampilkan yel-yel kelompok. Hal ini cukup menarik dan membangkitkan semangat sehingga peserta dapat kembali fokus dan semangat walau hari telah hampir sore.

Dari hasil observasi yang telah dilakukan selama pelatihan dapat diamati kendala-kendala yang dihadapi oleh guru diantaranya yaitu: 1) ada beberapa guru yang masih belum mengetahui meqip, 2) tidak adanya waktu untuk membuat media yang dapat membantu peserta didik agar mampu memahami pembelajaran dengan baik, 3) kurangnya sarana dan prasana atau dukungan, 4) ada beberapa guru yang masih kurang terampilnya dalam penggunaan media dan 5) Kurangnya pemahaman konsep yang dimiliki oleh guru.

Untuk kedepan setelah mengikuti pelatihan ini diharapkan guru-guru sekolah dasar mampu meningkatkan pemahaman konsep luas bidang datar kepada pesertadidik dengan memanfaatkan meqip. Dengan adanya kegiatan ini sekolah agar dapat memberikan dukungan sarana dan prasarana yang diperlukan oleh guru.pihak sekolah dan pemateri berharap untuk kedepan aka nada kegiatan serupa dalam meningkatkan kompetensi guru dalam proses pembelajaran.

Berdasarkan latarbelakang dan hasil Setelah Pelaksanaan Pelatihan dengan menggunakan Meqip dampak yang diperoleh baik bagi sekolah, Guru dan siswa, sangat signifikan sekali hal ini dapat dilihat dari antusias dari guru-guru yang awalnya ada yang belum mengenal meqip sekarang sudah dapat mengenal serta dapat mengimplementasikan pada saat proses pembelajaran. Selama Pelatihan Kebetulan Kepala sekolah menyempatkan untuk dapat terlibat langsung dalam kegiatan pelatihan, respon yang muncul dari kepala sekolah yaitu dalam hal ini sangat mendukung kegiatan pelatihan karena dapat meningkatkan kompetensi, kreativitas dan inovasi guru-guru sekolah dasar khususnya di SDN 008 Samarinda, sekolah juga mengharapkan untuk kedepan ada pelatihan yang serupa untuk diadakan di sekolah SDN 008 samarinda dan Sekolah juga menyampaikan akan mendukung dalam bentuk sarana dan prasana yang diperlukan guru dalam meningkatkan kompetensi anak didiknya.

Setelah pelaksanaan kegiatan ini diharapkan guru-guru memiliki peluang dalam meningkatkan perbaikan proses pembelajaran khususnya pembuatan media sebagai sarana pembelajaran di sekolah sehingga tujuan dari pembelajaran dapat tercapai dengan maksimal, sehingga pesertadidik secara tidak langsung mampu memahami konsep secara mendasar dengan mudah terhadap apa yang dijelasakan oleh guru ketika proses pembelajaran. Pelatihan Penggunaan media ini menjadi acuan agar guru-guru kreatif 
dan inovatif dalam pembuatan media pembelajaran, ketika proses pembelajaran berlangsung dapat mempermudah baik bagi guru maupun bagi siswa sehingga hasil pembelajaran yang diperoleh siswa dapat tercapai dengan maksimal. Karena pada prinsipnya media merupakan sarana yang sangat membantu guru dalam proses pembelajaran dengan tujuan agar siswa dapat maksimal dalam memahami apa yang disampaikan oleh gurunya, bukan dalam bentuk abstrak melainkan dalam hal yang nyata melalui media. Untuk melihat progresnya kami melakukan monitoring untuk tindak lanjut dari kegiatan pelatihan Meqip dimana monitoring atau pendampingan ini sebagai bukti kerjasama kami dengan pihak sekolah dan guru-guru. Untuk itu guru dituntut mampu mengembangkan dan membuat media secara kreatif dan inovatif untuk proses pembelajaran.

\section{Simpulan dan saran}

Berdasarkan dari hasil pelatihan dan pembahasan dapat disimpulkan bahwa rata-rata guru mampu memanfaatkan alat peraga yang tersedia di sekolah secara maksimal, dan mampu mengajarkan konsepkonsep matematika dengan benar sehingga siswa dapat mencapai tujuan pembelajaran dengan baik. Berdasarkan simpulan pengabdian yang telah dipaparkan, maka dapat diajukan beberapa saran guna peningkatkan kualitas pembelajaran matematika di Sekolah Dasar sebagai berikut. Pertama, hendaknya diperkenalkan dan dikembangkan kepada pendidik guna menciptakan suasana yang menyenangkan namun tetap fokus. Kedua, bagi lembaga pendidikan yang mengembangkan misi mendidik calon-calon guru, khususnya calon guru sekolah dasar, hendaknya terus menerus memperkenalkan dan melatih para calon guru untuk dapat menerapkan pembelajaran inovatif yang sesuai dengan karakteristik siswa di sekolah dasar. Sehingga pembelajaran yang diterapkan pada saat sudah menjadi guru nanti, lebih bermakna dan menyenangkan bagi peserta didik.

\section{Daftar Rujukan}

Alin ,Dyahsih (2015). Keefektifan Experiential Learning Pembelajaran Matematika Mts Materi Bangun Ruang Sisi Datar . Jurnal Riset Pendidikan Matematika Volume 2 - Nomor 2, November 2015, (175 185)

Atmaja, N, P. 2016. Evaluasi Belajar Mengajar. Yogyakarta. Diva Press,

Aziz, A. 2008. Metode dan Model-Model Mengajar IPS. Bandung,

Budiarto, M. T. (2006). Profil abstraksi siswa SMP dalam mengkonstruk hubungan antar segiempat. (Disertasi Doktor tidak dipublikasikan), Universitas Negeri Surabaya

Experiences". Journal International. Bill Usser. 2003. Interactions, Student Enthusiasm And Perceived Learning In An Online Teacher Education Degree.

Indayani ,Sri (2015). Profil Pemahaman Siswa Terhadap Luas Dan Keliling Bangun Datar Yang Digunakan Dalam Memecahkan Masalah Matematika Ditinjau Dari Kecerdasan Emosional ( Penelitian Pada Kelas Vii Mtsn Ketanggung Ngawi Semester Genap Tahun Pelajaran 2013/2014 ) . Jurnal Elektronik Pembelajaran Matematika ISSN: 2339-1685 Vol.3, No.3, hal 326-337 Mei 2015

Jacobs, HR. (1974). Geometry. San Francisco: WH Freeman and Company

Mahnun ,Nunu (2012). MEDIA PEMBELAJARAN (Kajian terhadap Langkah-langkah Pemilihan Media dan Implementasinya dalam Pembelajaran) . Jurnal Pemikiran Islam; Vol. 37, No. 1 Januari-Juni 2012

Mawardi. 2017.Merancang Model Dan Media Pembelajaran. Scholaria: Jurnal Pendidikan dan Kebudayaan. $8(1), 26-40$.

Novitasari ,Dian (2016). Pengaruh Penggunaan Multimedia Interaktif Terhadap Kemampuan Pemahaman Konsep Matematis Siswa . Jurnal Pendidikan Matematika \& Matematika Volume 2 Nomer 2 Desember 2016 
Purwono ,Joni (2014). Penggunaan Media Audio-Visual Pada Mata Pelajaran Ilmu Pengetahuan Alam Di Sekolah Menengah Pertama Negeri 1 Pacitan . Jurnal Teknologi Pendidikan Dan Pembelajaran Vol.2, No.2, Hal 127 - 144, Edisi April 2014

Rizal. 2010. Media Pendidikan: pengertian, pengembangan dan pemanfaatannya, edisi 1. Jakarta: Penerbit CV. Rajawali.

Sumarni (2013). Meningkatkan Hasil Belajar Matematika Materi Menghitung Volume Balok Dan Kubus Dengan Penggunaan Alat Peraga Kubus Satuan Pada Siswa Kelas Vi Sd Muhammadiyah 3 Surabaya . Jurnal PGSD Universitas Negeri Surabaya

Santyasa, I.W. 2007. Landasan Konseptual Media Pembelajaran. Disajikan dalam Workshop Media Pembelajaran bagi Guru-Guru SMA Negeri Banjar Angkan Pada tanggal 10 Januari 2007 di Banjar Angkan Klungkung (MEDIA-PEMBELAJARAN.PDF-Adobe Reader)

Suandito ,Billy (2017). Bukti Informal dalam Pembelajaran Matematika . Jurnal Pendidikan Matematika Vol. 8, No. 1, 2017

Sudjana.2009. Media Pembelajaran. Jakarta: Penerbit PT RajaGrafindo Persada.

Sundayana, Rostina. 2014. Media dan Alat Peraga dalam Pembelajaran Matematika. Bandung: Alfabeta.

Susanto, Ahmad. 2013. Teori Belajar dan Pembelajaran di Sekolah Dasar. Jakarta: Prenadamedia Group.

Suwangsih dan Tiurlina. 2006. Model Pembelajaran Matematika. Bandung: UPI Press.

Wijaya \& Rusyan. 2009. Pengenalan Media Pembelajaran. Disajikan untuk Bahan ajar untuk Diklat ETraining PPPPTK TK dan PLB (pengenalan-media-pembelajaran.PDF-Adobe Reader).

Yusuf ,Burhan (2015). Tujuan Besar Pendidikan Adalah Tindakan . Jurnal Prosiding Ks: Riset \& Pkm Volume: 2 Nomor: 2

Zainal, A. 2016. Evaluasi Pembelajaran. Bandung. PT Remaja Rosdakarya, 